taking a vote a large majority decided that some resolution should be framed. Not the least important feature of the meeting were the speeches made by Sir Frederick Young (formerly chairman of the "Forest Fund"), and others who had taken up an antagonistic attitude in the correspondence. Having visited the place and heard the explanations given on the ground, these gentlemen admitted that as the result of the afternoon's inspection they had seen good reason for modifying their views, and they finally voted for the following resolution, mored by Prof. Boulger and seconded by the Rev. IV. C. Howell, of Tottenham :- "That in the opinion of this meeting the general action of the Conservators in the recent thinnings has been judicious." Forty-one voted in favour of this resolution, and eight against. The views of those whose opinions should count for much in reassuring the public that no alarm need be felt as to the future of the Forest, have thus been expressed in very decided terms.

\section{THE UNIVERSITY OF LONDON.}

A GENERAL meeting of the Association for Promoting a Professorial University for London, was held in the rooms of the Chemical Society, Burlington House, on Saturday, April $2 S$; the Right Hon. T. H. Huxley was in the chair.

The committee reported that having carefully studied the report of the Gresham . Commission, they considered it is generally in accord with the principles of the Association.

In accordance with this report a resolution, moved by Prof. Rücker, and seconded by Prof. Ramsay, was unanimously carried, expressing general approval of the scheme. The committee were also empowered to draw up a memorial to the Government, to be signed by members of the Association, and others who may agree with it, urging the Government to appoint a Statutory Commission to establish a Teaching. University in London on the basis of the scheme of the Royal Commission.

This action on the part of the Association is, we hope, another step towards the realisation of the scheme of the "Gresham Commission."

It was at one time to be feared that it would be impossible to reconcile the various divergent views which had been expressed as to the best constitution for the University. Now, however, that the Colleges of Physicians and Surgeons, the Governing Body and Senate of University College, and the Professorial Association, have all expressed a general approval of the scheme, while the London County Council finds in it nothing inconsistent with its own views, it is evident that the Commissioners have achieved a remarkable success. The University of London has not yet spoken, but the oppo. nents of the scheme in Convocation were unable to carry their resolutions, and it is to be hoped that the University may yet be saved from the discredit of blocking the way.

\section{NOTES}

A STATUE of Durand-Claye, the pioneer of the system for the agricultural utilisation of sewage, was unveiled at Gennevilliers, on Friday last. The funds for the erection of this monument were raised by international subscription, in accordance with a proposal made at the Congress of Hygiene held in Paris in 1889.

WE regret to announce the death, at Geneva, of the eminent chemist; J. C. Galissard de Marignac. We have also to record the death of Laureano Calderon, Professor of Biological Chemistry in Miadrid University.

THE Kazan Society of Naturalists will celebrate the twenty-fifth anniversary of its foundation on May 25 , by a general meeting of members, at which a statement will be read of the works published by the Society during its existence.
The Times says that the Attorney-General has given his sanction to the sum of $f 25, c 00$, the residue of the legacy of the late Mr. Richard Berridge, being given, in trust, to the British Institute of Preventive Mledicine, for the endowment of a laboratory devoted to the bacteriological and chemical examina. tion of the water supply, with special reference to the best means of preventing the conveyance of disease through water. A large laboratory is now in course of erection for the purpose on the site secured by the institute at Chelsea.

Earthouakes continue to be felt in Greece. A severe dis. turbance, having its centre in Atalanti, occurred on Friday, April 27 (see p. 7), and the Times correspondent says that the inroads of the sea in this district have extended inland for a distance of three kilometres. The surface of the sea in many places is coloured with the products of submarine eruptions. A chasm has opened in the ground not far from Atalanti, and extends in a south-westerly direction for about twelve kilometres.

At the anniversary meeting of the Zoological Society, held on Monday, Sir William H. Flower, K.C.B., F.R.S., was reelected President, Mr. C. Drummond, Treasurer, and Dr. P. L. Sclater, F.R.S., Secretary to the Society for the ensuing year. The following were elected into the Council, in the place of retiring members:--Dr. John Anderson, F.R.S., Mr. Herbert Druce, Sir Joseph Fayrer, F.R.S., Major Henry P. St. John Mildmay, and Prof. A. Newton, F.R.S.

THE opening meeting of the British Association this year will take place on Wednesday, August $S$, when Prof. Burdon Sanderson, F.R.S., will resign the chair, and the Marquis of Salisbury will assume the presidency and deliver an address. On Thursday, August 9, a soirée will be held. On August 10, a discourse will be delivered by Dr. IV. H. IVhite, C.B., F.R.S., on "Steam Navigation at High Speeds"; on August 13, Prof. J. S. Nicholson will lecture on "Historical Progress and Ideal Socialism"; on August 14 there will be another soirce, and the concluding meeting will be held on Wednesday, August 15 .

THE committee for the establishment of a station at Cumbræ, for the study of marine zoology and botany, are making good progress with their arrangements. The $A r k$ has now been put into order for the summer months, and the services of an ex. perienced keeper secured. Mr. David Robertson, the well-known "naturalist of Cumbrre," takes a warm interest in the scheme, and is giving it his personal supervision. A number of students have intimated their intention of availing themselves of the facilities for research thus provided. $A$ con siderable sum has been subscribed for the erection of a permanent building, and also for the annual expenses of the station-about half of what is required in each case; and the committee have good hopes that the remaining half will soon be obtained.

THE Geologists' Association have arranged an excursion to Oxted and Titsey for Saturday next, under the direction of $\mathrm{M} r$. G. Leveson Grower and Mr. W. Topley, F.R.S. The district is not only interesting geologically, but contains a number of archæological remains. During IVhitsuntide a long excursion has been arranged to Cambridge and Ely, and on May $26 \mathrm{Mr}$. John Hopkinson and Mrr. Worthington G. Smith will conduct a party to Luton, Caddington, and Dunstable. In the neighbourhood of Caddington are numerous pits in Drift (brick-earth, \&c.), and Tertiary remanié beds, worked for clay and sand for brick-making, and for gravel. In these pits Mr. Smith discovered an old Palrolithic land-surface on Tertiary remanié, surmounted by re-laid Tertiary clay, and contorted, implementiferous red plateau drift. On this Palæolithic floor flint flakes of all kinds occur in hundreds, nearly all as keenedged as knives. That these fakes were made on the spot is

No. I 279 , VOL. 50] 